\title{
The Use of Audio-Visual Media in Milenial Instruction
}

\author{
Veronika Unun Pratiwi \\ Universitas Veteran Bangun Nusantara \\ Sukoharjo, Indonesia \\ pratiwiunun@yahoo.co.id
}

\begin{abstract}
Speaking is an important skill in learning English. Speaking can help students to understand the conversation, especially to understand the language function so the students can express their idea by using this games. Many students get difficulty to arrange the word to say the English word orally. The teachers get the same problem to teach speaking, especially for teacher who teaches in state school. It made the teacher tries to get solution to solve this problem. The objective of this study is to implement the technique to make the students understand how to speak. The researcher chose songs to help students understanding to speak , and also help the teachers to apply the new technique in teaching speaking for young learners. This research used descriptive qualitative research, the subject of this research is the third grade students of SDN Jombor 1 Sukoharjo. By applying the songs, the students speaking ability looks succeed, by using this games, the students become fun, enjoyable, and they more focus and interested in teaching learning activities. The students also have a self confidence in sharing their ideas through speaking in front of the classroom, they also can sing a new song happily.
\end{abstract}

\section{Keywords- song, speaking}

\section{INTRODUCTION}

Since humans are the social creatures who need each other, live alongside and interact with each other, language becomes the important role in human life. Absolutely, language is used by human as the media to interact, survive, and develop itself. It is a tool of communication to deliver thought, feeling, concept, and idea of human, such as in presentation, human expresses the idea to public and persuades them to choose certain decision [1] stated that :

Language is used for communication. Language allows people to say things to each other and express their communicative needs. Language is the cement of society, allow people to live, work and play together, to tell the truth but also to tell a lie.

Most people used English to communicate with other people from other country. English is our means of communication. English also a part of language that is taught in our country, start from kindergarten to University level.

One of the most important skills in teaching English is speaking. The third grades students have difficulties in speaking. Based on the problem, the researcher would conduct the research in this school, because after doing the observation the researcher found that the students have low interesting and focus in teaching learning speaking. By seeing this fact, the researcher used songs to apply in teaching speaking. This song makes the students happy and more active. They got the opportunities to speak and sing in front of the class.

Based on the background of this study the researcher formulates the problem as follow : How can Songs make the teaching speaking interest?

The objective of this study is to describe the use of song in teaching speaking.

\section{LITERATURE REVIEW}

\section{A. Definition of Speaking}

[2] said that speaking is the action of expressing oneself in speech or giving speeches. Speaking is the way to deliver something through word orally. Speaking can be assessed based on the fluency and accuracy. Students can speak fluently if they can master grammar, vocabulary and pronunciation well.

[3] stated that oral communication or speaking is a process between speaker and listener and involves the productive and receptive skill of understanding. It is clear that speaking is a part of daily life that happens between two people that are speaker and listener that necessary productive and understanding each other.

\section{B. Teaching Speaking}

[4] offered three phases in teaching speaking, as follow

1. Presentation Phase

Teacher should be more active than their students. Teacher gives the questions to dig the students knowledge and what the students know. Teacher asks the students to guess the meaning of the words in a grammatical structure.

2. Practice Phase

Teacher gives support and ensure to the students that they can speak accurately. When the students understand the meaning and use language and how it should be pronounced. The students should practice correctly.

3. Production Phase

Students should be able to use the language appropriately and accurately. Teacher should be organized the students activities, so the students can work in group like a discussion. So it will be more interesting if the students can speak in the class. 
[5] also described the techniques of classroom activities in teaching speaking, one of them is games. Games can create a relaxed atmosphere in teaching and learning process especially learning speaking. There are many kinds of games that can be used by teacher as a media of teaching speaking.

\section{Teaching Young Learners}

[5] stated that Children have many characteristics, one of them is they like playing, they talk about here and now, and they understand and retain the meaning better when they have seen more object associated with them. Children also like playing that make them happy, they also have a natural musical taste that playing when the children take seriously. Moreover, the implication of language teaching is that games are effective ways for teaching language and the children can play games during learn things while playing.

\section{Circle Games}

Teaching English to young learners usually effective if the teacher used an interesting media. Games is an interesting media that make the students feel fun and interested. There are many kinds of games, but in this research, the researcher chose circle games because there are lyrics of song or music instrumental in circle games that used to accompany the students when they draw or doing teaching learning activities in their classroom. Music can make the students more focus and enjoying the teaching learning process.

The procedure of circle games are the first the researcher helps the teacher to prepare the media such as music instrumental or children songs, a paper and a pencil. The teacher makes a circle or group that consists 3 to 4 students and gives them a topic that is determined by the teacher.

After a few minute, the teacher stops the music, and students stop drawing. The students give their drawing to the other students in one group. The teacher plays the music again and the next students continue to draw. The teacher stops the music again until the next students finishing the draw. Then the fourth students describes the picture. $t$ he or she has to describe the picture in front of the class.

Based on the procedure of the circle games, all of the students have a opportunity to speak in front of the class. They have a self-confidence to speak in front of their friends. This games can make the students feel fun, focus, and they have some opportunities to express everything on their mind like their ideas and passion.

\section{METHODS}

\section{A. Research Design and Setting}

This research the researcher used descriptive qualitative. The aim is to describe the impliatication of circle games in teaching speaking. The subject of this research is the students of the fifth grade of Elementary school. This subject is considered as young learners in learning English for the second time for them to learn English. The place of the research is in SDN Jombor 01 Sukoharjo.

\section{B. Data and Data Source}

The data which are used in this research the language function about expressing something. And the source of the data is the English teacher in SDN Jombor 03 Bendosari Sukoharjo. The data were taken by some methods.

\section{Technique of Collecting Data}

To collect the data before and after the research, this research needs:

1. Interview.

2. Observation

3. Documentation

The purpose this research to get the research of the data accurately. It is possible to collect the data, these data can be mixed from the three of them, they are; interview, observation, and documentation, and they are called triangulation.

Interview conducted twice during research. The first conducted in pre research that given to the teacher and the students. The first interview applied to get information about the situation class when the teacher taught English in class and the difficulties of the students to master English lesson especially Speaking in speaking skill.

The second interview was conducted after finishing implementation of game. The second interview was conducted to get information about the changing after and before. The researcher conducted observation during implementation of Circle Game media. The activities of students during implementing Game that were recorded by using check list observation.

The data of observation will be analyzed during implementation and will be taken the conclusion. The third collecting data method was using documentation. The documentation method as picture and recording when interviewed the teacher and students.

\section{Instrument}

In qualitative design, the main point of this research is the researcher herself or the team. But in this research the main instruments are interview, observation, and it is done by checking list and documentation by taking the picture from the data.

\section{E. Data Validity}

Qualitative research also needs triangulation of the data. It is also to check credibility of the data. According to [6] she stated the aim is not to determine the truth about some social phenomenon, rather the purpose of triangulation is to increase one's misunderstanding of whatever is being investigated.

In this research the validity of the data is tested by using triangulation from the three methods which have got. The credibility of the data is done by using observation, extension, and making a positive response to the students in speaking.

By using observation, extension, and making a positive response to the students in speaking, the researcher uses source triangulation. 


\section{F. Analysis Data}

In qualitative research, the technique of analysis the data are done frequently by collecting the various data, and do it continuously until the data saturated. According to [6] The researcher asks the informant/the source in order to get the right explanation related the information that is connected with the research. The researcher also collects the observation, interview, and the documentation. Even though the data are needed to describe, to be focused and then to be selected.

The Figure of the Data Analysis

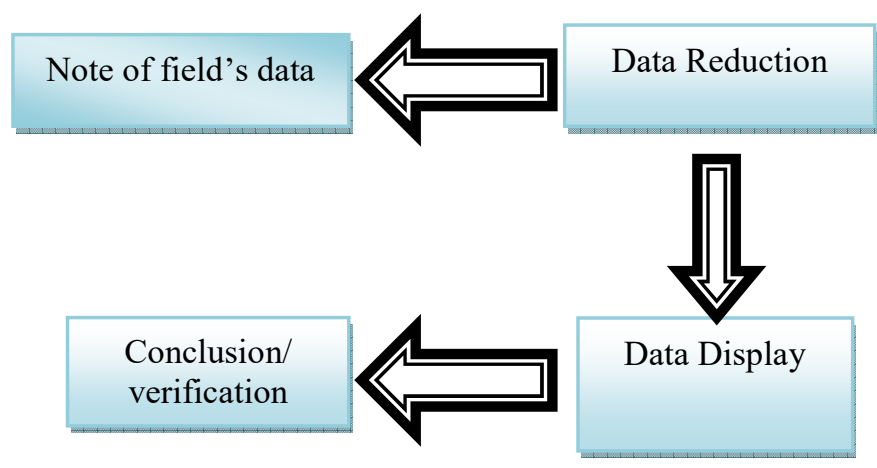

IV. RESULT AND DISCUSSION

This research used Circle Game in teaching Speaking at the fifth grade primary school student with implementation qualitative method specifically qualitative descriptive.

This research was started by interviewing the teacher and students. In this paper the researchers conducted observation to know the students' Speaking knowledge and the researcher got information about the difficulties of the teacher when she was teaching English. The interview showed how students' motivation was still low and students' achievement in English specifically in speaking because many students still got difficulties in Speaking. In Pre-test the researcher got low score from the students.

Finishing observation, the researcher began teaching Speaking using games about asking and giving something. In this activity can be found the students' motivation increased. Many students answered the teacher's question, besides that the students wanted to go to the front of the class to play the game. Their expression looked happy and enthusiast. In this action the researcher taught using using Game, the game is called Circle Game where played more than one student.

Circle Game is a media which is interesting to be conducted because make students more cheerful and interested on English learning. Further, the researcher explained new materials about language function In this time many students wanted to get chance playing game in the front of the class. [7] says that teaching is a complex and controversial profession, and the literature of education is full of teaching models that present varied conceptualizations of the nature of teaching. He adds that teaching includes activities (techniques and exercises) rationally selected by the teacher to help students achieve learning object.

Teaching is a complex, especially teaching students of elementary School as young learners because their characteristics are still childish and sometimes they made hectic situation. Teaching and learning process will be more interesting by learners if the teacher is able to teach the students by interesting media. Song and Game are interesting media. [8] mention that games have been long accepted in English language teaching because it can avoid students from stress in studying, from work that need high concentration and attention, and to remember things faster and better. It means that learning through game decreases the stress from lesson and makes the students enjoy the learning process. (e.g. board game, hangman, bingo, etc); it usually implies entertainment and relaxation.

Games are activities that encourage the participants to compete with one or with more individuals. They have certain rules. [9] say that game is an organized language activity that has a particular task and objective and a set of rules which involve an element of competition between players. Game is able to decrease the students' bored and make students to get more confident in teaching Speaking.

Based on the reality above, the team said that the learning activities can make the students more interesting to join the teaching learning English especially Speaking, these team also teach how to describe thigs. The team choose the fifth grade students, because they are considered have enough ability than fourth grade. The team teach speaking to the students, they imitate, and also repeat the words, they also listen the right spelling from the native speaker.

According to the field note before doing the research, before the teaching learning speaking, the students ability in speaking are still low. After the process of teaching learning by using circle games, their speaking improved. Related with the teaching learning activities, games give deep contribution in speaking. In other wise, if the teaching learning activities just explaining the material, that can make the students boring, and the class becomes noisy, and the students do not interest to join the class, especially in teaching learning English.

Based on the descriptive qualitative, by using games in teaching English, the students more interesting to learn English, they do not feel afraid or they consider that English is difficult but the students more active and more interest in teaching learning speaking, they feel happy, fun and enjoy joining the teaching learning English by using circle games.

\section{CONCLUSION}

Based on the finding and discussion, team conclude that;

This research about the Implication of Circle Games in teaching Speaking at the 5th grade students of SDN Jombor 1 Sukoharjo, the result is the students more enthusiastic and interest in joining the teaching learning speaking.

By using games, the teaching learning English become easy for the English teacher, the students' achievement can be improved, and the students motivation can be positively enhance. The delivering material is easier than just explanation. Besides teaching learning using songs make the students more interest, get fun, and enjoy in learning 
English. The choosing circle games appropriately can influence the best score in learning speaking. Besides games, the team also gave some songs to make the teaching learning exciting. It can be concluded that Song and game media is effective conducted in Elementary Student.

\section{ACKNOWLEDGMENT}

We want to say thank you for the ones who participate in doing this research, and also for our students in Veteran Bangun Nusantara University.

\section{REFERENCES}

[1] Suyanto, Kasihani K.E. English For Young Learners. Bumi Aksara, 2007.

[2] Hewings, Martin. Speaking Practice Through Interaction. Cambridge University Press, 1999.

[3] Hewings, Martin. Speaking Tasks. Cambridge University Press, 1993.

[4] Novitasari, Ika. Improving Students' Speaking Skill Through Circle Games. Thesis. Eglish Department Teacher Training and Education Faculty Veteran Bangun Nusantara University, 2013.

[5] Fauziati, Endang. Teaching English as a Foreign Language (TEFL). Surakarta : Universitas Muhammadiyah Surakata, 2005.

[6] Ary, Donald. Introduction to Research in Education. New York : Holt, Rinehart and Winston, 1979.

[7] Brown. N. Douglas. Principle of Language Learning and Teaching (Second Edition). New Jersey : Pretice-Hall, Inc, 1987.

[8] Latorre, G and G. Baeza. "The Contribution and the Use of EFL Crossword Puzzle.” ELT . Journal: Vol xxx. No. 1 October. 1975, 1975.

[9] Celce, M and Murcia. Teaching English as a Second or Foreign Language. Boston :Heinle \&Heinle, 2001. 